\title{
The Significance of the Blood Glucose Level for Plasma Insulin Response to Intravenously Administered Tolbutamide in Healthy Subjects*
}

\author{
E. Cerasi, I. Chowers**, R. Luft and A. Widström \\ Department of Endocrinology and Metabolism, Karolinska Hospital, Stockholm, Sweden
}

Received: June 23, 1969

\begin{abstract}
Summary. The effect of intravenous tolbutamide on insulin release in normal human subjects was investigated under various experimental conditions. The blood glucose level was either allowed to fall after i.v. tolbutamide or kept within normal limits by a concomitant glucose infusion. In other experiments, tolbutamide was given during different degrees of hypoglycaemia induced by insulin. It was found that tolbutamide provoked a rapid and short-lasting insulin release as well as a post-initial and extended insulin release, provided the blood glucose concentration was kept within normal limits. The hitherto accepted transiency of tolbutamide action in healthy subjects seems to be due to the hypoglycaemia which follows the administration of the drug. During more marked hypoglycaemia induced by exogenous insulin, the insulin releasing capacity of tolbutamide was almost blunted. Tolbutamide markedly enhanced the insulin release following glucose administration. The findings presented might clarify some of the therapeutic effects of the drug in diabetes mellitus.
\end{abstract}

Le rôle de la glycémie pour l'effet insulinosécréteur du tolbutamide administré par voie endoveineuse chez des sujets normaux

Résumé. L'effet du tolbutamide intraveineux sur l'insulino-sécrétion a été étudié chez des sujets normaux dans des conditions expérimentales variées. Dans une série d'expériences on laissa baisser la glycémie à la suite du tolbutamide, tandis que dans une autre le sucre sanguin était maintenu dans les limites de la normale grâce à une perfusion de glucose suivant l'injection de tolbutamide. Dans d'autres expériences, le tolbutamide a été administré pendant que les sujets étaient hypoglycémiques à la suite d'une injection intraveineuse d'insuline. Les résultats obtenus démontrent que le tolbutamide, à condition de maintenir la glycémie dans les limites de la normale, provoque une insulino-sécrétion aussi bien rapide et de courte durée que prolongée et de type post-initial. L'aspect passager de l'action du tolbutamide chez l'homme normal admis jusqu' à maintenant comme inhérent à la drogue, semble être dû à l'hypoglycémie provoquée par son administration. En effet quand le tolbutamide était administré durant une hypoglycémie plus prononcée, le pouvoir insulinosécréteur de la drogue diminuait encore ou disparaissait totalement. La réponse insulinique à l'hyperglycémie était augmentée par l'administration ultérieure de tolbutamide. Les résultats ci-dessus pourraient être importants pour la compréhension de l'effet thérapeutique du tolbutamide dans le diabète humain.

Die Bedeutung des Blutzuckerspiegels für die Insulin: freisetzung nach intravenöser Zufuhr von Tolbutamid bei gesunden Personen

Zusammenfassung. Die Wirkung intravenöser Zufuhr von Tolbutamid wurde bei gesunden Versuchspersonen unter verschiedenen experimentellen Bedingungen untersucht. Den Blutzuckerspiegel ließ man nach der Zufuhr abfallen oder hielt ihn durch gleichzeitige Glucoseinfusion auf normalen Werten. In anderen Versuchen wurde Tolbutamid bei verschiedenen Stufen von Insulinhypoglykämie gegeben. Dabei ergab sich, daß Tolbutamid sowohl eine schnelle und kurzdauernde wie auch eine post-initiale und langdauernde Insulin-freisetzende Wirkung ausübte, vorausgesetzt, daß die Blutzuckerkonzentration auf normaler Höhe gehalten wurde. Die bis jetzt akzeptierte, vorübergehende Tolbutamidwirkung bei Gesunden scheint durch die Hypoglykämie, die der Zufuhr der Droge folgt, verursacht zu sein. Während einer deutlicheren, durch Insulin induzierten Hypoglykämie war die Insulinfreisetzende Wirkung des Tolbutamid fast ausgelöscht. Tolbutamid verstärkte die Insulinfreisetzung auf Glucoseinfusion beträchtlich. Diese Befunde mögen für die Interpretation der therapeutischen Wirkung des Tolbutamid bei Diabetes mellitus von Bedeutung sein.

Key-words: Tolbutamide, insulin secretion in humans, action of tolbutamide.

\section{Introduction}

The main pharmacologic action of tolbutamide is the stimulation of insulin release from the pancreatic $\beta$-cells. It has been demonstrated both in human experiments (YALOW et al., 1960; CerasI and LUFT, $1967 \mathrm{~b}$; PFETFEER, 1967), and in vitro using the isolated perfused rat pancreas (Grodsky et al., 1967a, b; CURRY et al., 1968; Loubatił̀res, 1968), that insulin release after tolbutamide is transient, its duration

* This study was supported by grants to E.C. and R.L. from the Swedish Medical Research Council (B69 $-19 \mathrm{X}-34-05 \mathrm{~A}$ ) and the Knut and Alice Wallenberg Foundation.

** Present adress: Department of Medicine, Hadassah Medical Organization, Jerusalem, Israel. being much shorter than the half-life of the drug. Furthermore, it has been stated that the insulin releasing action of tolbutamide in vitro is not dependent on the presence of glucose (COORE and RANDLE, 1964a, b; Creutzereldt et al., 1967; Curry et al., 1968; Grodsky et al., 1967 a, b; LoubatiÈres, 1968; Malatsse et al., 1967; Malaisse and Malaisse-Lagat, 1968). Against this background it would be difficult to understand how the sulphonylureas administered once or a few times daily could exert a long-lasting therapeutic effect in some diabetic patients. On the other hand, in diabetic subjects the fall in blood sugar after tolbutamide is delayed and less pronounced than in normals (Unger and Madison, 1958). This raises the question 
whether the transient insulin response to the drug in normals could still be due to the ensuing hypoglycaemia.

The present experiments were performed with the aim of assessing the significance of the blood glucose level for the insulin releasing effect of tolbutamide in humans.

\section{Material and Methods}

Ten healthy non-obese subjects were studied, three females and seven males. Their mean age was 27 years, with the range $19-52$ years. All had a normal intravenous glucose tolerance test and a normal increase in insulin concentration on glucose infusion.

All tests were performed with the subjects on a free diet and after an overnight fast. Blood glucose was measured with a glucose oxidase method, insulin in plasma with a double-antibody radioimmunoassay according to HALES and RANDLE (1963).

The glucose infusion test (GIT) has been described earlier (CERASI and LUFT, 1967a). The relationship between the concentrations of blood glucose and plasma insulin was calculated with the aid of an analogue computer (CERAsi, 1967).

Tolbutamide in all tests was given intravenously over a period of $2 \mathrm{~min}$ in a dose of $1 \mathrm{~g}$. The following sets of experiments were performed:

A) Tolbutamide was injected at zero time, and venous blood samples for determination of blood glucose and plasma insulin concentrations were drawn at $-5,0,5,10,15,20,25,30,40,50,60 \mathrm{~min}$. The test was performed in six subjects.

B) Tolbutamide was injected at zero time, and this was followed immediately by the constant infusion of $0.01 \mathrm{~g}$ of glucose per $\mathrm{kg}$ body weight per min for $60 \mathrm{~min}$. Blood samples were drawn as in experiment A. Seven such tests were performed in six subjects.

C) At zero time 0.05 or $0.1 \mathrm{U}$ of glucagon-free insulin (Actrapid, Novo) per $\mathrm{kg}$ body weight was injected intravenously. Tolbutamide was injected $30 \mathrm{~min}$ later. After another $30 \mathrm{~min}, 0.1 \mathrm{~g}$ of glucose per $\mathrm{kg}$ was injected intravenously, followed by an infusion of $0.01 \mathrm{~g}$ of glucose per $\mathrm{kg}$ per $\mathrm{min}$ for $30 \mathrm{~min}$. Venous blood samples were drawn at $-5,0,5,10,20,30,35$, $40,45,50,55,60,65,70,80,90 \mathrm{~min}$. The test was performed in nine subjects with the lower insulin dose. Four of these were tested also with the higher dose.

D) To assess whether prior administration of tolbutamide might modify the insulin response to glucose, tolbutamide was injected $30 \mathrm{~min}$ before a GIT. This test was performed in five subjects.

\section{Results}

A) The results of this series of experiments are summarized in Fig. 1. Tolbutamide administration was followed by a rapid and transient increase in plasma insulin reaching a maximum around $5 \mathrm{~min}$, and returning to the fasting level about $50 \mathrm{~min}$ after the injection (range 40-60 $\mathrm{min}$ ). During the test the glucose concentration decreased about $50 \%$, with a tendency to increase again during the last $20 \mathrm{~min}$ of the test.

B) In the next series, hypoglycaemia was prevented in all subjects but one (in whom blood glucose concentration was $42 \mathrm{mg}$ per $100 \mathrm{ml}$ at $30 \mathrm{~min}$, and 30 at $60 \mathrm{~min}$ ). The mean curve for blood glucose reached a maximum of $85 \mathrm{mg}$ per $100 \mathrm{ml}$, corresponding to an increase of $10 \mathrm{mg}$ per $100 \mathrm{ml}$ over the fasting level at
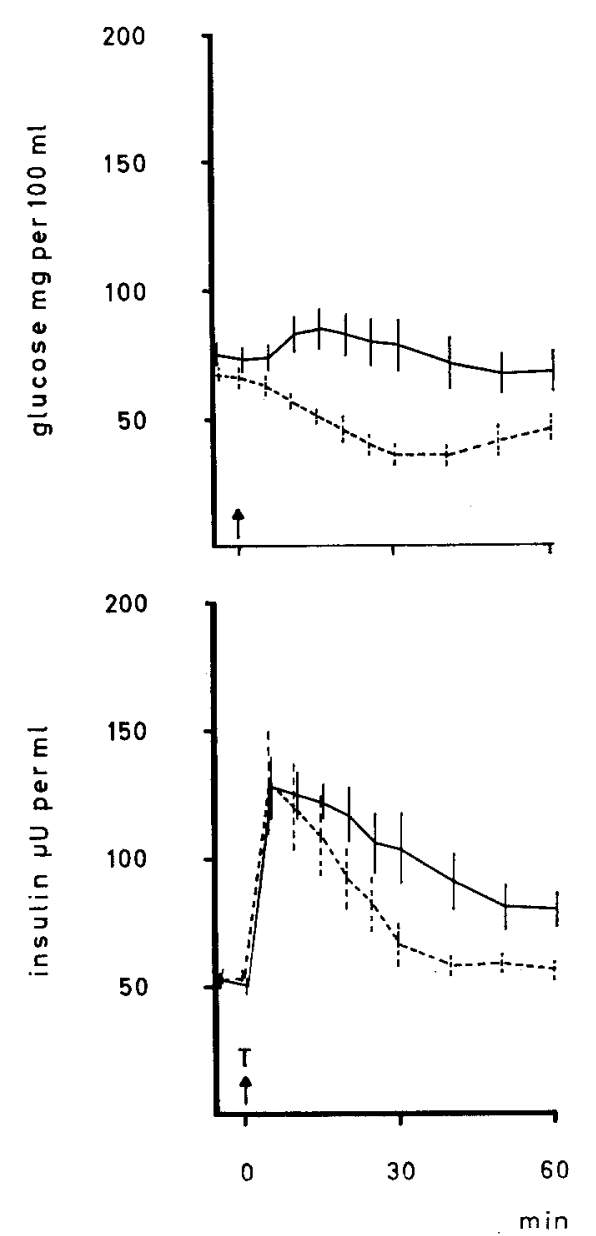

Fig. 1. Effect of intravenous tolbutamide (given at arrow) on plasma insulin concentration in healthy subjects. Broken line with tolbutamide alone, solid line with tolbutamide followed by an infusion of glucose during $0-60 \mathrm{~min}$. Vertical bars denote the S.E. M.

$15 \mathrm{~min}$, and then slowly returned to the fasting level. Plasma insulin concentration showed the same rapid increase as in $A$, but the return to the fasting level was much slower (Fig. 1).

C) Fig. 2 gives the mean values for blood glucose and plasma insulin in the experiments. At the time of injection of tolbutamide, blood glucose concentration had decreased to about $50 \%$ of the starting level. The administration of tolbutamide was followed by a 
transient increase in insulin concentration of smaller magnitude and shorter duration than in experiment A. Glucose injection and infusion 30 minutes later was followed by another increase in plasma insulin, which remained elevated throughout the infusion.

With the higher insulin dose the blood glucose decreased to about $25 \%$ of the starting level, and showed a faster return than with the low insulin dose. The increase in insulin concentration after tolbutamide this time was much smaller than with the lower dose.
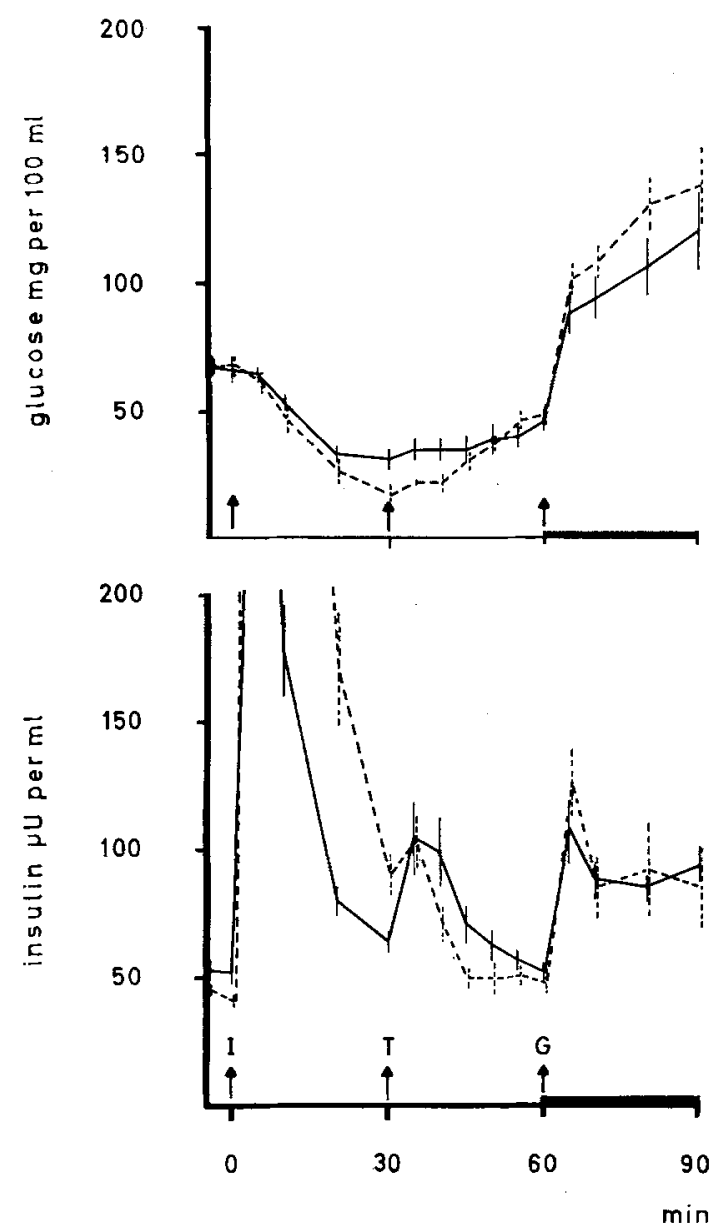

Fig. 2. Effect of insulin-induced hypoglycaemia on plasma insulin-response to tolbutamide. Insulin was given at I, tolbutamide at $T$ and priming dose of glueose at $G$, followed by a glucose infusion during $60-90 \mathrm{~min}$. Solid lines denote results with the insulin dose of $0.05 \mathrm{U} / \mathrm{kg}$, dotted lines with $0.10 \mathrm{U} / \mathrm{kg}$. Vertical bars stand for the S. F.M.

Fig. 3 summarizes the relationship between glucose concentration and the effect of tolbutamide on insulin release in experiments $A$ and $C$. The insulin response to tolbutamide, measured as the area below the insulin curve, showed a highly significant correlation to the blood glucose level at the time of the injection of tolbutamide $(r=0.646, P<0.005)$.
D) Tolbutamide administration, as in experiment $A$, was followed by an increase in insulin and a decrease in giucose concentration. During the GIT, plasma insulin again responded with a marked initial peak almost twice as high as after tolbutamide, and a second phase lasting as long as the glucose infusion (Fig. 4). The effect of prior tolbutamide administration on the insulin response to glucose is demonstrated by the change in the parameters of the computer simulation: $k_{i_{1}}$, reflecting the amount of insulin released in

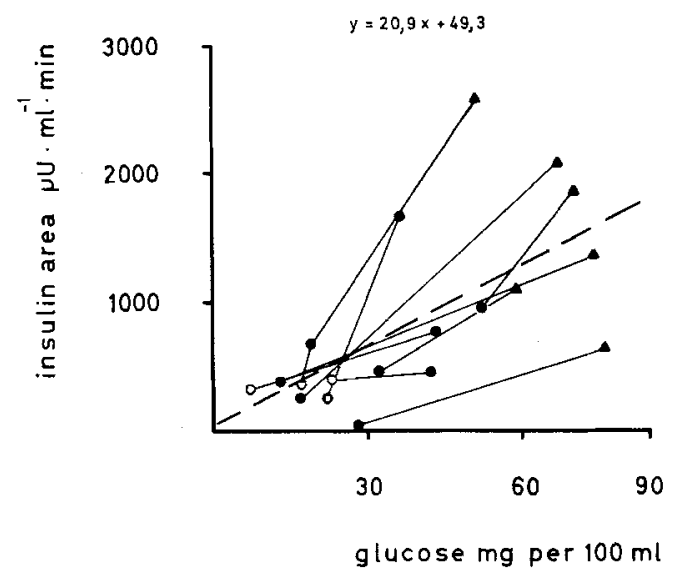

Fig. 3. Relationship between insulin response to tolbut. amide and blood glucose level at the time of the tolbutamide injection. Triangles denote results from experiment A, filled circles with the lower insulin dose of experiment $\mathrm{C}$, open circles with the higher insulin dose (see also text). Solid lines connect results in the same subjects, broken line is the regression line for all results.

proportion to the initial rise in blood glucose, increased from 2.48 to $2.85 ; k_{i_{2}}$, reflecting the amount of insulin produced and released during the glucose infusion in relation to the glucose level, from 2.70 to $3.00 ; b$, expressing the slope of plasma insulin increase due to glucose infusion, was increased from 2.37 to 2.64. On the other hand $k_{g}$, expressing the biological activity of endogenous insulin, remained unchanged (1.33 with tolbutamide, 1.34 without). Thus, tolbutamide increased both the initial and the later insulin responses to glucose, particularly the former, while it did not change the effect of insulin on glucose removal.

\section{Discussion}

The results of experiment $A$ of the present study show the well-known pattern of insulin response to intravenous tolbutamide administration, i.e. an increase in plasma insulin of much shorter duration than the half-life of tolbutamide which is $100-150 \mathrm{~min}$ (VINIK et al., 1968). The type of plasma insulin curve obtained in these experiments is compatible with an insulin release from the pancreas of a duration of about 5-7 min as shown by us in an earlier study (CERAsI, 1967). A similar pattern was demonstrated by CURRY et al. (1968), Grodsky et al. (1967a, b), and LoubA- 
TIÈRES (1968) using the rat pancreas perfused in vitro. According to Grodskr et al. and CurRy et al., this transiency of the insulin response corresponds to the emptying of an easily available small insulin pool in the $\beta$-cells of the pancreatic islets, or, alternatively, to the induction of a refractory state after the initial release due to some metabolic change within the $\beta$ cells.

The results of our experiment $B$, in which the tolbutamide-induced hypoglycaemia was prevented

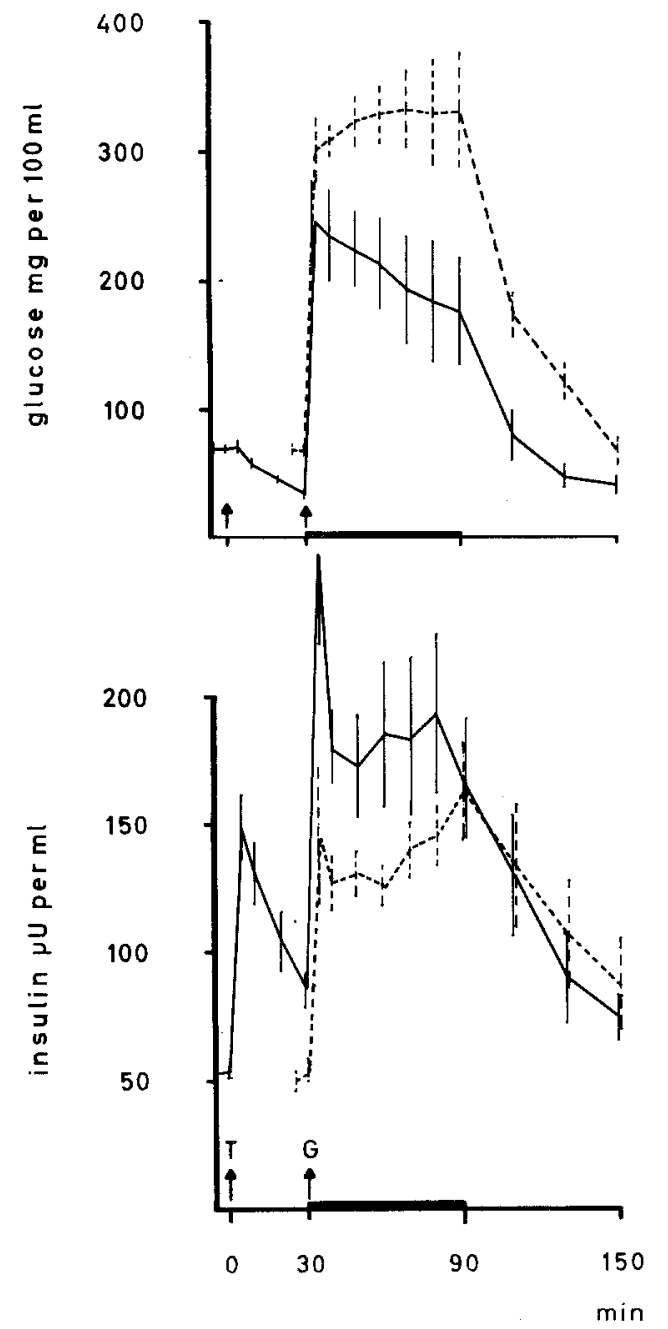

Fig. 4. Effect of tolbutamide $(T)$ on the insulin response to glucose. Glucose, $0.5 \mathrm{~g} / \mathrm{kg}$, was injected at $\mathrm{G}$, followed by an infusion of $0.02 \mathrm{~g} / \mathrm{kg} . \mathrm{min}$ between 30 and $90 \mathrm{~min}$. Broken lines denote results obtained with glucose alone, solid lines when the glucose infusion was preceeded by tolbutamide. Vertical bars stand for the S.E.M.

by the infusion of enough glucose to keep the blood glucose concentration within normal limits, are in contradiction to these explanations. Insulin release under these conditions resembled more that induced by glucose infusion where a rapid initial release is followed by a second slower phase of secretion (CERASI and
LuFr, 1967a; CuRry et al., 1968). The slight increase in blood glucose concentration in these experiments (of about $10 \mathrm{mg}$ per $100 \mathrm{ml}$, or from 75 to $85 \mathrm{mg}$ per $100 \mathrm{ml}$ as a mean; Fig. 1) was probably of no significance in this connection, since it is accepted that insulin release is induced only when blood glucose exceeds $80-90 \mathrm{mg}$ per $100 \mathrm{ml}$ (Loubatik̀res, 1968). The results of experiment $\mathrm{D}$ in which glucose, given $30 \mathrm{~min}$ after tolbutamide, was accompanied by a substantial insulin release also speak against the above two hypotheses.

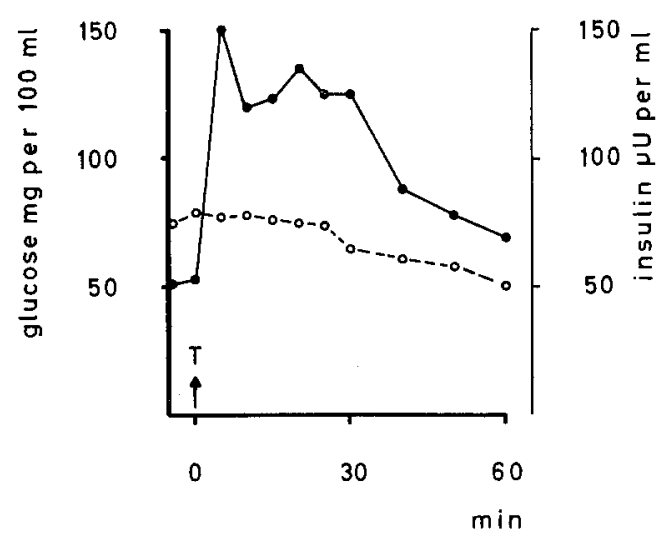

Fig. 5. Plasma insulin and blood glucose responses to tolbutamide in one patient with mild diabetes mellitus. Filled circles and solid lines shows the plasma insulin level, open circles and dotted line blood glucose.

Thus it can be concluded that, at least in humans, tolbutamide exerts a rapid and short-lasting as well as a post-initial and extended insulin release provided the blood glucose concentration is kept within normal limits. This implies either that the effect of tolbutamide on the $\beta$-cell is dependent on the presence of glucose or a metabolite of glucose, or that a glucose-independent, insulin-releasing effect of tolbutamide is inhibited by the hypoglycaemia which follows the administration of the drug. To our knowledge, no experiments in animals, in vitro or in vivo, have been presented so far which consider the effect of tolbutamide on the different stages of insulin release in relation to the concentration of glucose. What has been shown is, that tolbutamide in the absence of glucose in the medium elicits insulin release of the transient initial type (CURRY et al., 1968; GRoDsky et al., 1967 a, b; LoUBATIìRES, 1968). This does not, however, exclude a dependence of this insulin release on glucose, since the $\beta$-cell is relatively rich in glycogen (SAMOLS et al., 1966; HELLMAN and IDAHL, 1969), and tolbutamide has been shown to increase the oxygen consumption of isolated islets even with no substrate in the medium (HELLERSTRÖM, 1968). It is therefore plausible that the breakdown of intracellular glycogen furnishes the glucose necessary for the tolbutamide action during the initial phase. It is totally unknown whether glycogen in the human $\beta$-cell plays a role in the release of insulin.

The second possibility - a glucose-independent in- 
sulin release - is partly ruled out by the fact that tolbutamide in vitro, in a medium without glucose, did not elicit a postinitial insulin release (see above). The effect of hypoglycaemia on the tolbutamide-induced insulin release was further illustrated by experiment C. During hypoglycaemia, tolbutamide could elicit only an initial insulin response (Fig. 2). The magnitude of this response was inversely correlated to the degree of hypoglycaemia (Figs. 2 and 3). In some instances tolbutamide failed to elicit any increase in plasma insulin during hypoglycaemia.

Hypoglycaemia in vivo could still inhibit insulin release through its stimulating effect on the secretion of catecholamines, which suppress this release (PoRTE et al., 1966; Porte, 1969; Senft et al., 1968). Catecholamines were not measured in our experiments, but it has been shown that adrenaline concentration in blood increases as soon as the blood glucose starts to decrease after an insulin injection, and the peak is reached within $10 \mathrm{~min}$ after the lowest glucose values (Vendsalu, 1960). However, in experiment $\mathrm{C}$ elimination of hypoglycaemia 30 min after tolbutamide was followed by instantaneous elevation of plasma insulin. Since it is unlikely that the catecholamine concentration would be normalized within the few minutes of the glucose injection, this speaks in favour of blood glucose concentration per se being of major importance in this connection.

The above discussion has been focused around the significance of a normal or subnormal blood glucose concentration for the insulin-releasing action of tolbutamide. The effect of tolbutamide on the glucoseinduced insulin-release is illustrated in Fig. 4, experiment D. Insulin response to glucose was strongly enhanced by prior tolbutamide administration. It cannot be decided whether this enhancement was of additive or potentiating character, since the effect of tolbutamide per se on insulin release during hyperglycaemia remains unknown. For the same reason, the claims by LoUBATrìnes (1968) that this synergism is of potentiating nature, and those by MaLAISSE et al. $(1967,1968)$ that an additive synergism is more likely, seem to us unwarranted.

The present studies have revealed that the effect of tolbutamide on insulin release is modified by the concentration of blood glucose, and that tolbutamide, provided that hypoglycaemia is prevented, has a protracted action. This has some bearing on the therapeutic action of tolbutamide in diabetes. It is well known that in diabetics the blood glucose fall is delayed and less pronounced than in normals when the drug is given intravenously. Fig. 5 clearly shows that, at least in some patients, plasma insulin response to intravenous tolbutamide may be protracted and very similar to that obtained in experiment B (Fig. 1).

Acknowledgements. The authors wish to thank Mr. A. Roovete, Mrs. Christina Thornquist, Mrs. Kerstin Waldelöf, Miss Gundie Sandgren and Miss Anette JoHANSSON for valuable assistance.

\section{References}

Cerasi, E.: An analogue computer model for the insulin response to glucose infusion. Acta endocr. (Kbh.) $\mathbf{5 5}$, $163-183$ (1967).

-, and R. LuFT: The plasma insulin response to glucose infusion in healthy subjects and in diabetes mellitus. Acta endocr. (Kbh.) 55, 278-304 (1967a).

- - Further studies on healthy subjects with low and high insulin response to glucose infusion. Acta endocr. (Kbh.) 55, 305-329 (1967 b).

Coore, H.G., and P.J. RANDLE: Regulation of insulin secretion studied with pieces of rabbit pancreas incubated in vitro. Biochem. J. 93, 66 (1964a).

- Insulin secretion from rabbit pancreas in vitro. In: The structure and metabolism of the pancreatic islets, p. 295. S.E. Brolth, B. Hellman, and H. Knutsson, Eds. Oxford: Pergamon Press 1964b.

Creutzfeldt, W., H. Frerichs, and C. Creutzfeldt: Studies with tolbutamide on islet tissue in vitro and islet homografts. In: Tolbutamide ... after ten years, No. 149 , p. 34. W.J.H. BUTTERFIELD, and W. VAN Westering, Eds. Amsterdam: Excerpta Med. Int. Congress Ser. 1967.

Curry, D.L., L.L. Bennetr, and G.M. Grodsky: Dynamics of insulin secretion by the perfused rat pancreas. Endocrinology 83, 572-584 (1968).

Grodsky, G.M., D.L. Curry, L.L. BennetT, and B. LECHARNY: Factors infuencing insulin release in vitro. Symposium at the Medical Division of the Oak Ridge Institute of Nuclear Studies, Nov. 13 (1967a).

- L.L. Bennetr, D. Smith, and K. Nemecher: The effect of tolbutamide and glucose on the timed release of insulin from the isolated perfused pancreas, No. 149 , p. 11. In: Tolbutamide ... after ten years. W.J.H. ButTerfteld, and W. van Westering, Eds. Amsterdam: Excerpta Med. Int. Congress Ser. $1967 \mathrm{~b}$.

HALES, C.N., and P.J. RANDLE: Immunoassay of insulin with insulin-antibody precipitate. Biochem. J. 88, $137-146$ (1963).

Hetuerström, C: Effects of glucose and hypoglycaemic sulfonylureas on the metabolism in vitro of pancreatic $\beta$-cells. Diabetologia 4, 245 (1968).

Hellman, B., and L. A. IDAHL: Presence and mobilization of glycogen in mammalian pancreatic $\beta$-cells. Endocrinology 84, 1-8 (1969).

LoubATIÈREs, A.: Stimulators and inhibitors of insulin secretion, physiological and pharmacological interferences, synergism and antagonism. In: Mechanism and regulation of insulin secretion. $R$. LFVINE, and E.F. Pfeiffer, Eds. Acta Diabetologica Latina 5, suppl. 1, p. 220, 1968.

Mataisse, W.J., and F. Malaisse-Lagat: Stimulation of insulin secretion by noncarbohydrate metabolites. J. Lab. clin. Med. 72, 438-448 (1968).

- - D.A. MaYhew, and P.H. Wright: Effects of sulfonylureas upon insulin secretion by the rat's pancreas. In : Tolbutamide . . a after ten years, No. 149, p. 49. W.J.H. BUTTERFIELD, and W. VAN WERSTERING, Eds. Amsterdam: Excerpta Med. Int. Congress Ser. 1967.

PFEIFFER, E.F.: Dynamics of insulin secretion in normal, obese and diabetic subjects following beta-cell stimula. tion. In: Tolbutamide ... a after ten years, No. 149 , p. 127. W.J.H. ButTERFIELD, and W. VAN WESTERING Eds., Amsterdam: Excerpta Med. Int. Congress Ser. 1967.

Porte Jr., D.: Sympathetic regulation of insulin secre. tion. Its relation to diabetes mellitus. Arch. intern. Med. 123, 252-260 (1969). 
- A. L. Graber, T. KuzuYa, and R. H. Williams: The effect of epinephrine on immunoreactive insulin levels in man. J. clin. Invest. 45, 228-236 (1966).

SAMOLS, E., G. MARRI, and V. MARKs: Interrelationship of glucagon, insulin and glucose. The insulinogenic effect of glucagon. Diabetes 15, 855 --866 (1966).

Sexte, G., R. Sitr, W. Losert, G. Sohultz, and M. HOFFMAN: Hemmung der Insulininkretion durch $\alpha$ Receptoren stimulierende Substanzen. Naunyn-Schmiedebergs Arch. Pharmak. exp. Path. 260, 309-323 (1968).

Unger, R.H., and L.L. Madison: A new diagnostic procedure for mild diabetes mellitus: Evaluation of an intravenous tolbutamide response test. Diabetes $\mathbf{7}$, $455-461$ (1958).
VENDSALU, A.: Studies on adrenaline and noradrenaline in human plasma. Acta physiol. scand. 49, suppl. 173, p. $33(1960)$.

VINIK, A.I., W.P.U. JACkson, P. KeliLeR, and N. MARINE: Metabolic studies in diabetics on tolbutamide. Comparison of a single dose with a divided dose regimen. Diabetologia 4, $203-209$ (1968).

YALOW, R.S., H. BLAOK, M. VILLAZON, and S.A. Berson: Comparison of plasma insulin levels following administration of tolbutamide and glucose. Diabetes $9,356-$ 362 (1960).

E. Cerasi

Dept. of Endocrinology

and Metabolism

Karolinska Sjukhuset

Stockholm 60, Sweden 